\title{
OIL SECTOR: POTENTIAL FOR TAX INCENTIVES ${ }^{1}$
}

\author{
Yu. Bobylev, O. Rasenko
}

The state of Russia's oil sector is marked by a general deterioration of the oil extraction conditions owing to depletion of existing deposits in developed regions and significantly higher extraction costs at the new oil fields and tight oil deposits. In order to improve the situation, investments in the development of new oil fields are required as well as in deepened development of existing deposits with an improved refining margin. Government fiscal policy should contribute to the resolution of these issues including implementation of structural reform in the tax system and introduction of special excess-profit tax.

At present, Russia's oil-producing industry is at the peak of its production capacity. Considerable part of the producing oil fields is at the declining production stage and the new oil deposits in the majority of cases are of inferior mining-and-geological and geographic parameters. Development of these deposits requires higher capital, operating, and transport costs. In order to maintain the achieved volumes of oil extraction, it is necessary to reactivate both non-producing reserves in the developed regions and to develop fields in the new production regions as well as improve additional extraction on producing deposits owing to their deeper exploitation. There is a high potential in the oil refining depth, which according to its technical level is no match to the level achieved by the developed countries.

Implementation of the structural reform in the tax system triggers the creation of tax incentives in upgrading of the downstream segment. That reform includes gradual reduction of export duty on crude oil and petroleum products (down to their total revocation) and increase of the role of mineral extraction tax (MET) $)^{2}$. Reduction of export duties results in cutting subsidies extended to the oil-refining sector and putting in place real incentives aimed at increasing the refining depth. Improved refining depths will lead to satisfaction of the domestic demand in motor oil amid relatively lower volumes of crude oil consumption.

As for 2016, reduction of the export duty was frozen (it was retained at the 2015 level) in order to increase state budget revenue and excises on petroleum products were raised by way of additional measure aimed at increasing revenue. We think that reduction of export duty could have been a more preferable solution. Both growing excises and reduction of export duty result in the growth of domestic prices on motor oil and increase of the budget revenue (both owing to MET growth rate and due to profits growth of oil pro-

1 This paper was originally published in Online Monitoring of Russia's Economic Outlook No.10(28).

2 See: Idrisov G., Sinelnikov-Murylev S. Modernization or conservation: the role of export duty on oil and petroleum products. Ekonomicheskaya politika. 2012. No.3, pp. 5-19; Bobylev Yu, Idrisov G., Sinelnikov-Murylev S. Export duties on oil petroleum products: need to revoke and scenario analysis of consequences. Moscow, Gaidar Institute Publishers, 2012; Bobylev Yu. Tax maneuver in the oil sector. Russian economic Developments. 2015. No.8, pp. 45-49; Idrisov G., Kaukin A. Tax maneuver: economic growth acceleration to the detriment of budget consolidation. OMREO, No.9 (27) May 2016, pp. 11-15. 
ducers thanks to domestic price growth). However, reduction of export duty allows obtaining additional positive effects - stimulate modernization of the oil-refining sector and cut subsidization of the EAEU member states.

Introduction of a special excess-profits tax (EPT) at the new oil fields will be a driver of the development of the oil extraction sector. The EPT tax base is the difference between the cost of production and sale of hydrocarbons and costs of production and sale of products (minus depreciation), production capital investments, and irrecoverable costs of the previous fiscal period.

Application of the EPT progressive rate, which depends on the project's profitability represents an important factor. Profitability is measured by $\mathrm{P}$-factor value, which is calculated as correlation of aggregate production profit and crude oil sale to aggregate capital and production costs. With P-factor's growth, the tax rate increases from 10 to $80 \%$ (Table 1).

This tax will ensure tracking of all rent-shaping factors and will automatically bring tax burden in line with actual economic efficiency of oil fields exploitation. In case of highly efficient projects, imposition of EPT will ensure progressive rent collection in favor of the state. At the same time, indispensable conditions will be put in place for the implementation of unproductive projects.

Table 1

EXCESS-PROFITS TAX RATE IN OIL EXTRACTION

\begin{tabular}{|c|c|}
\hline P-factor ( $t-1)$ & $\begin{array}{c}\text { Excess-profits tax } \\
\text { rate }(\mathrm{t}), \%\end{array}$ \\
\hline To 1.00 & 0 \\
\hline From 1.00 to 1.10 & 10 \\
\hline From 1.10 to 1.20 & 15 \\
\hline From 1.20 to 1.30 & 20 \\
\hline From 1.30 to 1.40 & 30 \\
\hline From 1.40 to 1.50 & 40 \\
\hline From 1.50 to 2.00 & 50 \\
\hline From 2.00 to 2.50 & 60 \\
\hline From 2.50 to 3.00 & 70 \\
\hline Over 3.00 & 80 \\
\hline
\end{tabular}

Sources: IEP, RANEPA.

It is feasible to levy EPT in conjunction with MET, which in such cases would be as a minimum guarantee tax ensuring a certain minimum level of proceeds from project's realization. Inasmuch as EPT is the main rent tax, MET amid EPT implementation should be levied at a rather low rate, for example, at ad valorem rate of $15 \%$. Introduction of EPT will ensure a secured revenue to the state from the date of commencement of the crude oil production (through commencement of profit tax receipts) as well as in cases of low crude oil prices and high production costs. The crude oil export duty should be set at zero in the wake of levying EPT.

The EPT regime with a progressive tax rate ensures the tax system progressivity. On the back of growing world oil price, the government take in net income from crude oil production grows. At the same time, amid low oil prices as well as high production costs, the government take in net income falls, thus forming more favorable economic conditions for the development of high production costs oil fields.

According to our calculations computed with the help of a simulation model for the development of a typical oil field, implementation of EPT in 
conjunction with MET levied at ad valorem rate of $15 \%$ and zero export duty rate ensures increase of tax revenue from $70.2 \%$ from obtained net income at oil price of $\$ 40$ per barrel to $83.9 \%$ at the price of $\$ 120$ per barrel (Table 2). Furthermore, at $\$ 40$ per barrel and more the investor is guaranteed required return on investments (internal rate of return exceeds $16.3 \%$ ).

Table 2

\section{INDICES OF THE TAX BURDEN AND EFFICIENCY OF INVESTMENT IN OIL EXTRACTION IN THE CONTEXT OF EFFECTIVE FISCAL SYSTEM AND EPT REGIME}

\begin{tabular}{|c|c|c|c|c|c|c|}
\hline \multirow{2}{*}{ Tax regimes } & \multicolumn{6}{|c|}{ World oil price, \$/bbl. } \\
\hline & 40 & 50 & 60 & 80 & 100 & 120 \\
\hline \multicolumn{7}{|c|}{ 1. Effective fiscal system (with privileges on MET): } \\
\hline Government take in proceeds, $\%$ & 53.8 & 57.8 & 60.8 & 64.5 & 66.7 & 68.2 \\
\hline $\begin{array}{l}\text { Government take in } \\
\text { net revenue, \% }\end{array}$ & 92.7 & 89.1 & 85.9 & 82.6 & 80.9 & 79.8 \\
\hline Internal rate of return, $\%$ & 6.4 & 11.5 & 16.2 & 22.8 & 27.8 & 31.8 \\
\hline \multicolumn{7}{|c|}{ 2. EPT regime (EPT $=10-80 \%, M E T=15 \%, E D=0)$ : } \\
\hline Government take in proceeds, $\%$ & 41.9 & 49.3 & 54.9 & 64.1 & 69.9 & 72.7 \\
\hline $\begin{array}{l}\text { Government take in } \\
\text { net revenue, \% }\end{array}$ & 70.2 & 72.8 & 75.1 & 80.2 & 82.3 & 83.9 \\
\hline Internal rate of return, \% & 16.4 & 19.3 & 21.8 & 25.3 & 27.7 & 30.3 \\
\hline
\end{tabular}

Source: own calculations.

Progressive tax rate has some advantages compared to a single tax rate. In the context of a single tax rate, the multiplicity of mining-and-geological and geographic conditions of development of Russia's oil deposits and considerable differences in economic efficiency of projects are taken into consideration to a lesser degree. In case of highly efficient projects, this will result in shortfall by the state of certain part of resource rent. In case of unproductive projects, the single rate can become excessively high, which will hamper their realization.

According to our calculations, at a standard oil field EPT regime with a progressive tax rate in the range of 10 to $80 \%$ and a single tax rate of $50 \%$ creates approximately identical tax burden at price of oil of $\$ 50$ per barrel. Meanwhile, compared to a single tax rate progressive tax rate guarantees higher share of the state in income obtained from crude oil extraction amid higher oil prices and ensures lower tax burden in the context of lower oil price (Fig. 1).

The progressive rate has similar advantages in the wake of higher and lower production costs. In the context of higher production costs, it ensures a lower tax burden compared to a single tax rate, i.e. more favorable conditions for investment in the development of high-cost deposits.

Introduction of the excessiveprofit tax will allow to ensure a wider

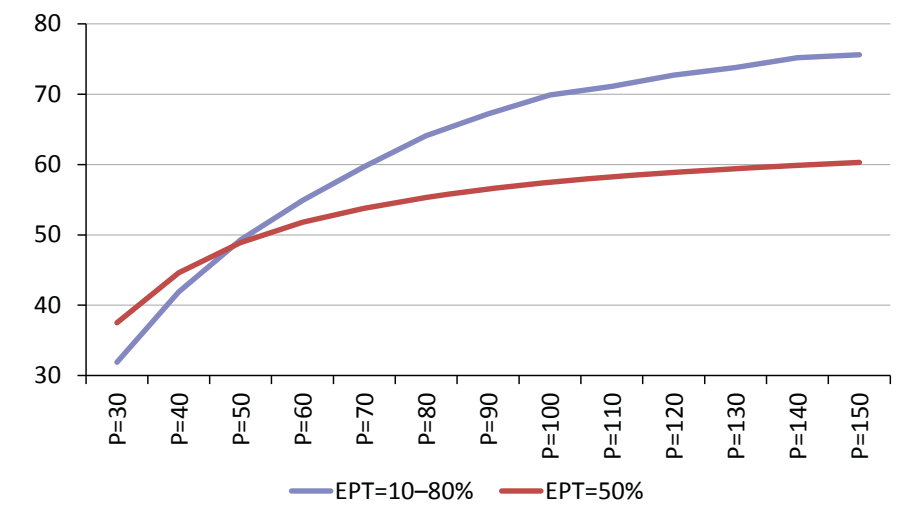

Source: own calculations.

Fig. 1. The share of state in income obtained from oil extraction in the context of progressive tax rate and single EPT rate, \% to proceeds 
differentiation of the tax burden and create necessary conditions for investment in the development of the high-cost deposits. At the same time, such tax is a more complicated form of taxation, which implementation requires corresponding tax administration.

Levying of EPT is also feasible at the producing (brown fields) fields. However, it is more difficult from the point of view of tax administration. Stimulation of deeper exploitation of existing fields can be achieved with the use of a less complication tax mechanisms. A more significant reduction of MET rate against the currently effective one for the deposits with depleted resources can represent another solution. This will reduce the tax burden at mature oil fields and will provide incentives for their deeper exploitation and increase of oil recovery coefficient. 